Research Article

\title{
High levels of genetic variability and differentiation in hilsa shad, Tenualosa ilisha (Clupeidae, Clupeiformes) populations revealed by PCR-RFLP analysis of the mitochondrial DNA D-loop region
}

\author{
Sabuj Kanti Mazumder and Md. Samsul Alam \\ Department of Fisheries Biology and Genetics, Bangladesh Agricultural University, Mymensingh, \\ Bangladesh.
}

\begin{abstract}
The hilsa shad, Tenualosa ilisha (Clupeidae, Clupeiformes) is an important anadromous clupeid species from the Western division of the Indo-Pacific region. It constitutes the largest single fishable species in Bangladesh. Information on genetic variability and population structure is very important for both management and conservation purposes. Past reports on the population structure of $T$. ilisha involving morphometric, allozyme and RAPD analyses are contradictory. We examined genetic variability and divergence in two riverine (the Jamuna and the Meghna), two estuarine (Kuakata and Sundarbans) and one marine (Cox's Bazar) populations of $T$. ilisha by applying PCR-RFLP analysis of the mtDNA D-loop region. The amplified PCR products were restricted with four restriction enzymes namely, Xbal, EcoRI, EcoRV, and Haelll. High levels of haplotype and gene diversity within and significant differentiations among, populations of $T$. ilisha were observed in this study. Significant $F_{\mathrm{ST}}$ values indicated differentiation among the river, estuary and marine populations. The UPGMA dendrogram based on genetic distance resulted in two major clusters, although, these were subsequently divided into three, corresponding to the riverine, estuarine and marine populations. The study underlines the usefulness of RFLP of mtDNA D-loop region as molecular markers, and detected at least two differentiated populations of $T$. ilisha in Bangladesh waters.
\end{abstract}

Key words: genetic variability, PCR-RFLP, mtDNA, Tenualosa ilisha.

Received: April 10, 2008; Accepted: July 24, 2008.

\section{Introduction}

The hilsa shad, Tenualosa ilisha, belonging to the sub-family Alosinae of the family Clupeidae (Clupeiformes, Pisces), occurs in foreshore areas, estuaries, brackish-water lakes and freshwater rivers of the western division of the Indo-Pacific faunistic region. Its marine distribution extends from Iran and Iraq in the Persian Gulf to the west coast of India in the Arabian Sea and the Bay of Bengal (Pillay and Rosa Jr, 1963).

Hilsa shad is the largest single fishable species in Bangladesh, present in almost all the major river systems, estuaries and marine environments (Bay of Bengal), and at present contributing to approximately $12 \%$ of the total fish production and $20 \%$ of fishery-capture (inland and marine) with a biomass of 78, 273 metric tons from inland fisheries and 198, 850 metric tons from marine (DoF, 2006). Hilsa is termed the national fish of Bangladesh, due to its popularity and economic importance. However, the production of hilsa in Bangladesh has waned when compared to earlier

Send correspondence to Md. Samsul Alam. Department of Fisheries Biology and Genetics, Bangladesh Agricultural University, Mymensingh, Bangladesh. E-mail: samsul_bau@yahoo.com. estimates. Until 1972, hilsa shad fishery was prosperous upstream in the rivers of Bangladesh, especially in the Padma and Meghna. Fishery has entered into a severe decline upstream and is nowadays mainly concentrated downstream, as well as in estuaries, coastal areas and the sea (Nurul Amin et al., 2004). Due to the low water discharge from the upstream Ganges at the Farakka barrage (in West Bengal, India) with the consequent heavy siltation, the indiscriminate exploitation of juveniles ( Jatka), disruption of migration routes, loss of spawning, feeding and nursing grounds, increased fishing pressure, etc., have all contributed to this decline.

The hilsa shad is largely an anadromous species, but two other ecotypes - a fluvial potamodromous type and a marine type - have been recognised. The potamodromous stocks appear to remain in the middle reaches of the rivers throughout the year and breed therein. The anadromous stocks, whose normal habitat is the lower region of the estuaries and the foreshore areas, ascend the rivers during the breeding season and return to the original habitat after spawning (Raja, 1985). The upstream migration during the main breeding season depends largely on the commencement of the south-west monsoon and consequent flooding 
of the major rivers of Bangladesh, Burma and India. However, the exact spawning season for the species is still controversial, as spawning varies from a few months to all the year round. However, it is not known whether migratory populations mix during migration or whether they pass each other spatially and temporally. Therefore, the exact stocks are still in dispute.

Reports on the stock structure of the valuable tropical shad T. ilisha, based on samples collected from Bangladesh and India and through morphometric, allozyme and RAPD analyses, are contradictory. Dahle et al.(1997) claimed to have discriminated three populations of hilsa shad in Bangladesh waters, such as Chandpur (Meghna river), Barguna (Brackish water, estuarine) and Cox's Bazar (sea water) by using RAPD markers. On the basis of a single polymorphic locus, PGM, Rahman and Naevdal (2000) claimed that there existed two separate gene pools of hilsa shad in Bangladesh waters. Milton and Chenery (2001), on the basis of otolith chemistry and morphometry, and Salini et al. (2004), on the basis of allozyme and morphometric analyses, inferred, however, that there was a single stock of hilsa in Bangladesh waters, this including the Bay of Bengal. Brahmane et al. (2006) identified two groups of T. ilisha in India, one comprising the Ganges and Yamuna rivers and the other the Hooghly and Narmada rivers, by using RAPD markers.

Among the different markers available for population genetic analysis, differences in mitochondrial DNA are probably the most widely used, since they follow maternal inheritance, do not undergo rearrangements or recombination and present higher mutation rates than those of nuclear genes (Avise, 2004). RFLP analysis of the mtDNA control region is a simple technique for revealing genetic variation in the mitochondrial genome of an organism.

In this study, we analyzed haplotype and gene diversity in five samples of T. ilisha, using PCR-RFLPs of the mtDNA D-loop region as genetic markers. The aim of the present study was to compare mtDNA genetic diversity in T. ilisha samples collected from rivers, estuaries and the sea, and to delineate genetic differentiation among populations of the three major aquatic environments. We also report here whether there are any genetic differences between distant river populations of T. ilisha, as well as between estuarine populations. The purpose of the present study is to examine the usefulness of mitochondrial D-loop region diversity to supplement allozyme and RAPD data on the population genetic structure of T. ilisha.

\section{Materials and Methods}

\section{Fish samples and extraction of DNA}

Ninety hilsa (T. ilisha), with an average body weight of about $400 \mathrm{~g}$, were collected from five geographic locales: Balashi (Gaibandha, upstream of the Jamuna River)), Chandpur (middle of the Meghna River), Kuakata (estuar- ies), Sundarbans (estuaries) and Cox's Bazar (Bay of Bengal) with the help of artisanal fishers (Figure 1). Immediately after landing the fish on board, a piece of dorsal fin from each was carefully collected and preserved in $95 \%$ ethanol. The samples were stored at $-20^{\circ} \mathrm{C}$ until further use for the extraction of DNA. Total DNA (nuclear + mitochondrial DNA) of each individual fish was extracted from approximately $50 \mathrm{mg}$ of fin tissue by standard proteinase-K digestion, phenol:chloroform:isoamyl alcohol extraction and the alcohol precipitation method as described by Islam and Alam (2004). The quality of the DNA samples was checked by electrophoresis on $1 \%$ agarose gel and the quantity determined by using a spectrophotometer, prior to PCR amplification of the mtDNA D-loop region.

\section{Amplification of mitochondrial DNA}

The $2.2 \mathrm{~kb}$ D-loop region of the mtDNA, including a part of the cytochrome $b$ and 12SrRNA genes, was amplified from each of the 90 samples by using the primer-pairs L-12260 ( $5^{\prime} \rightarrow 3$ ', CAT ATT AAA CCC GAA TGA TAT TT) and H-1067 (5' $\rightarrow$ 3', ATA ATA GGG TAT CTA ATC CTA GTT T) (Martin et al., 1992). The mtDNA fragment was amplified in a reaction volume of $30 \mu \mathrm{L}$ containing $75 \mathrm{ng}$ template DNA, $3 \mu \mathrm{L}$ of $10 \mathrm{X}$ buffer $(100 \mathrm{mM}$ Tris- $\left.\mathrm{HCl}, \mathrm{pH}=8.3,15 \mathrm{mM} \mathrm{MgCl}_{2}, 500 \mathrm{mM} \mathrm{KCl}\right), 3 \mu \mathrm{L}$ of $2.5 \mathrm{mM}$ dNTPs (dATP, dCTP, dGTP, dTTP), $1 \mu \mathrm{M}$ of each primer and 2 units of Taq DNA polymerase (GENEI Ban-

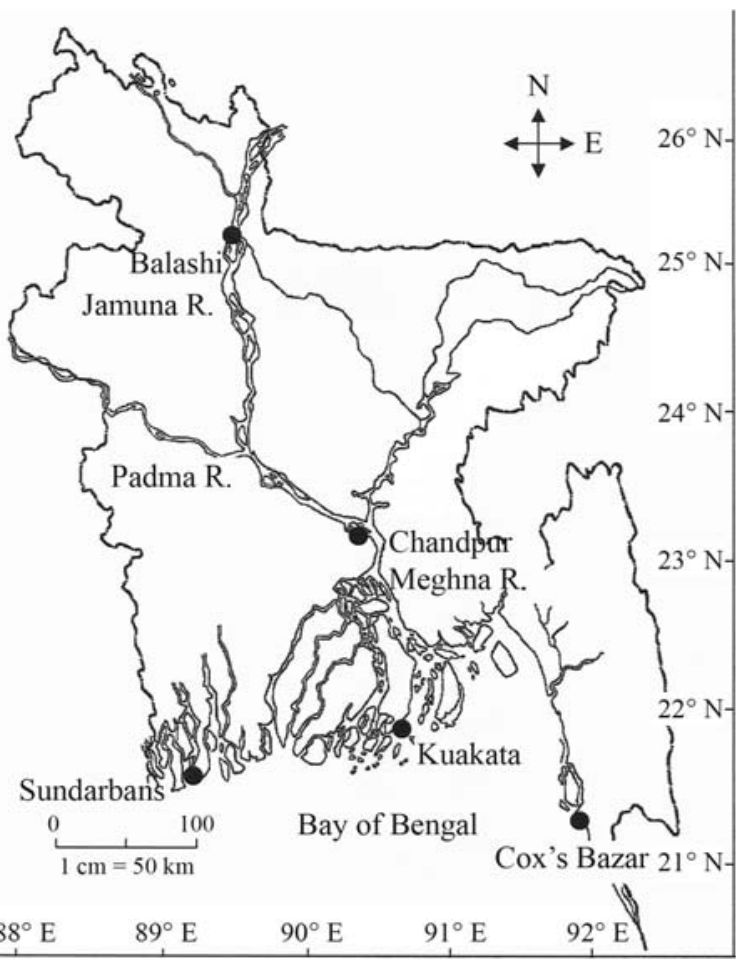

Figure 1 - Map of Bangladesh showing the five sites $(\bullet)$ from where the samples of $T$. ilisha were collected. The three big rivers, the Padma, Jamuna and Meghna, are also shown. These three rivers constitute the major riverine fishery of $T$. ilisha in Bangladesh. R: river. 
galore, India). An oil-free thermal cycler (Master Cycler Gradient Eppendorf, Germany) was used for PCR amplification with the following cycle parameters: initial denaturation at $94{ }^{\circ} \mathrm{C}$ for $3.0 \mathrm{~min}$, followed by 35 cycles of denaturation at $94{ }^{\circ} \mathrm{C}$ for $45 \mathrm{~s}$, annealing at $45^{\circ} \mathrm{C}$ for $45 \mathrm{~s}$ and extension at $72{ }^{\circ} \mathrm{C}$ for $2.0 \mathrm{~min}$. A final extension step at $72{ }^{\circ} \mathrm{C}$ for 7 min followed the last cycle. The PCR products were confirmed by electrophoresis on agarose gel and subjected to digestion with restriction endonucleases.

\section{RFLP analysis}

Four restriction enzymes ( $X b a \mathrm{I}, E c o$ RI, EcoRV and HaeIII) were used for digesting the amplified fragments. Ten microlitres of the PCR product were used for each digestion following manufacturer's (Promega) recommended conditions. The restricted PCR products were electrophoresed on $1.4 \%$ agarose gel containing ethidium bromide and photographed under UV light using a Geldoc camera (UVP Inc). Two molecular weight markers, $\lambda$ DNA-HindIII digest and 100 bp DNA ladder were run on each gel along with the digested PCR products. The sizes of mtDNA restriction fragments were measured by using the software, DNAfrag (Nash, 1991).

\section{Genetic data analysis and dendrogram construction}

Restriction patterns generated from each restriction endonuclease were given letter designations in the order of their frequencies. Haplotype A refers to the most common digestion pattern in the analyzed samples. The remaining alphabetical profile names (B, C, etc.) indicate variant digestion patterns reflecting their frequencies in order. Composite haplotypes were constructed from all the enzymes used and arranged from the enzyme generating the fewest polymorphic patterns to that generating the most ( $X b a \mathrm{I}$, EcoRI, EcoRV and HaeIII in this order). The presence or absence of restriction sites in the control region was inferred for each of the four enzymes from a series of restriction fragment patterns. The site codes across the amplified region for a restriction enzyme were concatenated and each fish was assigned a code of four letters that described its composite, multi-enzyme haplotype.

A single data matrix comprising the composite haplotypes and their frequencies in the five populations was constructed. Haplotype and gene diversity, both calculated as per Nei (1987), and a hierarchical analysis of population subdivision performed using the analysis of molecular variance with 1000 simulated samples (AMOVA, Excoffier et al. 1992), were implemented in ARLEQUIN v. 3.1 (Excoffier et al., 2005). Both the Tajima (1989) D-test and the Fu (1997) Fs-test were applied to test deviations from neutral molecular evolution. Significance was assessed in both cases by generating random samples (number of simulated samples: 1000) under the hypothesis of selective neutrality and population equilibrium, as implemented in ARLEQUIN. Significance levels of pair-wise $\mathrm{F}_{\mathrm{ST}}$, under the hypothesis of no differentiation between populations, were determined by means of 10000 permutations of haplotypes between populations. Genetic distance values between population-pairs were calculated from the $\mathrm{F}_{\mathrm{ST}}$ values of the respective population-pair by using the formula: $\mathrm{D}$ $($ genetic distance $)=-\log \left(1-\mathrm{F}_{\mathrm{ST}}\right)($ Reynolds et al., 1983). Distance data were used to draw up an unweighted pairgroup method of averages (UPGMA) dendrogram by using MEGA version 4 (Tamura et al., 2007) software.

\section{Results}

PCR amplification of the D-loop region resulted in a product of approximately $2.2 \mathrm{~kb}$ with no detectable size differences between $T$. ilisha samples. Using this sequence, four restriction enzymes (XbaI, EcoRI, EcoRV and HaeIII) were selected to obtain RFLP markers. All enzymes produced polymorphic banding patterns and restriction sites. Restriction of the PCR fragment with the four restriction endonucleases resulted in a total of 35 restriction profiles in the samples collected from five locations in Bangladesh. The cleavage patterns and estimated lengths of the restriction fragments for different restriction enzymes are shown in Table 1. The cleavage patterns produced due to variations in restriction sites were three for $X b a \mathrm{I}$ and $E c o$ RI, five for EcoRV and seven for HaeIII. In some cases, however, the sum of the fragment sizes did not exactly equal the total size of the amplified region, probably due to small fragments being lost or bands of similar size co-migrating. The 35 different haplotypes (composite genotypes) detected in 90 individuals of the five populations, along with their numerical frequencies, are presented in Table 2.

Out of the 35 haplotypes, only two, VI and XI, were distributed randomly among the five populations, the others being either specific for a particular population or shared by two or three (mostly two) populations (Table 2). Haplotypes II, III, IV, V, VII, IX and X were specific to the Balashi population, XII and XIII to the Chandpur, XVII, XVIII, XIX, XXI, XXIII, XXIV, XXV and XXVI to the Cox's Bazar, XXVII, XXVIII, and XXIX to the Sundarbans and XXXV to the Kuakata. Haplotype I was shared by the Balashi, Chandpur and Sundarbans populations, VIII by the Balashi and Chandpur, XVI by the Chandpur and Sundarbans and XX by the Cox's Bazar and Kuakata. Haplotype I was dominant in the Balashi and Chandpur population, haplotype VI in the Chandpur, haplotypes XVII and XX in the Cox's Bazar and XXVIII in the Sundarbans. None of the haplotypes were found to be dominant in the Kuakata population.

Polymorphic haplotypes were observed in all the five populations. The rates of haplotypes (number of haplotypes observed divided by the sample size) ranged from 0.500 (Chandpur) to 0.722 (Sundarbans) (Table 3). Haplotype diversity was high in all the five populations, ranging from 0.882 (Chandpur) to 0.960 (Sundarbans). The average gene diversity across the loci was highest in the Sundarbans pop- 
Table 1 - Restriction patterns for different haplotypes in the $2.2 \mathrm{~kb}$ mtDNA D-loop fragment from ninety T. ilisha collected from five locations in Bangladesh (values show restriction fragment in bp).

\begin{tabular}{|c|c|c|c|c|c|c|c|c|}
\hline \multirow[b]{2}{*}{ Restriction enzyme } & \multirow[b]{2}{*}{ Recognition sequence } & \multicolumn{7}{|c|}{ Haplotypes } \\
\hline & & A & B & $\mathrm{C}$ & $\mathrm{D}$ & E & $\mathrm{F}$ & G \\
\hline \multirow[t]{2}{*}{$X b a \mathrm{I}$} & T/CTAGA & 1608 & 1241 & 2168 & & & & \\
\hline & & 568 & 930 & & & & & \\
\hline \multirow[t]{3}{*}{ EcoRI } & G/AATTC & 1439 & 1566 & 1529 & & & & \\
\hline & & 566 & 566 & 566 & & & & \\
\hline & & 95 & & & & & & \\
\hline \multirow[t]{2}{*}{ EcoRV } & GAT/ATC & 1432 & 1296 & 1296 & 1375 & 1432 & & \\
\hline & & 707 & 707 & 675 & 707 & 675 & & \\
\hline \multirow[t]{4}{*}{ HaeIII } & $\mathrm{GG} / \mathrm{CC}$ & 680 & 680 & 680 & 680 & 1210 & 680 & 849 \\
\hline & & 660 & 660 & 660 & 660 & 580 & 660 & 680 \\
\hline & & 440 & 541 & 409 & 580 & 200 & 409 & 660 \\
\hline & & 425 & 200 & 390 & 200 & & 200 & \\
\hline
\end{tabular}

ulation (0.569) and lowest in the Kuakata (0.343). The overall Fixation Index $\left(\mathrm{F}_{\mathrm{ST}}\right)$ across the populations was 0.092 and the population specific $\mathrm{F}_{\mathrm{ST}}$ indices ranged from 0.085 (Sundarbans) to 0.105 (Chandpur). Tajima's D test (Tajima, 1989) and Fu's F test (Fu, 1997) were not significant $(\mathrm{p}>0.05)$ in all the populations.

Variance components and F-statistics analogs (Phist) were calculated with AMOVA. No significant differences among samples were found. Hierarchical analyses indicated that $90.78 \%$ variation was contained within local populations while $9.22 \%$ was distributed among the populations. However, significant differentiation $\left(\mathrm{F}_{\mathrm{ST}}\right)$ values were found among the five populations of T. ilisha. The $\mathrm{F}_{\mathrm{ST}}$ value between the Chandpur and Sundarbans populations was the highest and that between the Chandpur and Balashi the lowest. The $\mathrm{F}_{\mathrm{ST}}$ values between the Balashi-Chandpur, Cox's Bazar-Kuakata, and Sundarbans-Kuakata population pairs were insignificant, while these values between the remaining seven were found to be significant (Table 4). Genetic distance values calculated from the corresponding $\mathrm{F}_{\mathrm{ST}}$ values between the population-pairs are shown in Table 4. The highest genetic distance was observed between the Chandpur and Sundarbans population, while the lowest was observed between the Chandpur and Balashi population. The UPGMA dendrogram based on genetic distance resulted in two clusters. The first cluster contained four populations and the second contained only the Cox's Bazar population. The first cluster was subsequently divided into two sub-groups. The two river populations, Balashi and Chandpur, formed one group and the two estuarine populations, Kuakata and Sundarbans, the second (Figure 2).

\section{Discussion}

Mitochondrial DNA-RFLP has been proved to be an effective technique for population discrimination. The present study was an attempt to reveal genetic variability and stock discrimination of hilsa populations in Bangla- desh waters, including freshwater, estuarine and marine environments, by PCR mtDNA RFLP analysis.

The detection of 35 different haplotypes in only 90 individuals of five $T$. ilisha samples underlines the usefulness of RFLPs of the D-loop region as molecular markers for investigating the geographic structure of the species. High diversity indices were obtained within each sample (Table 3). The average haplotypic diversity in T. ilisha observed in the present study, fell within the upper part of the range (0.473-0.998) for some other fishes as reported by Avise et al. (1989), and reached as high as that (0.892) obtained in red seabream collected from four locations of western Japan through PCR-RFLP analysis of the mtDNA D-loop region by Tabata and Mizuta (1997). However, since the estimation of haplotype diversity is based on haplotype frequencies alone, it is dependent on the number of restriction enzymes used (Graves and McDowell, 1994). These results suggest that genetic variability in T. ilisha is quite high. High levels of genetic diversity appear to be commonly observed in migratory fishes with large panmictic populations (Santos et al., 2007). This is because large effective population size and high migration rates minimize the effect of genetic drift as a force that lowers intra-population genetic variability. However, the presence of private alleles indicates that these populations are not completely panmictic. The non-significant values ( $p>0.05$ ) obtained from Tajima's D and Fu's Fs statistical tests indicate that the sampled populations of T. ilisha are in genetic equilibrium, which means that apparently there is no pressure of selection on the population with regard to mitochondrial DNA haplotypes.

The test for population differentiation gave significant $p$-values $(\mathrm{p}<0.05)$, indicating that composite haplotypes were not distributed randomly with respect to locality. F-statistics (Weir and Cockerham, 1984) yielded an overall $\mathrm{F}_{\mathrm{ST}}$ value of 0.092 which indicates that genetic exchange occurring among the populations was not sufficient to prevent either genetic differentiation or structuring into genetically differentiated subpopulations in T. ilisha in 
Table 2 - Geographic distribution of 35 composite mtDNA D-loop region haplotypes among five conspecific populations of $T$. ilisha based on four restriction enzymes ( $X b a \mathrm{I}, E c o R I, E c o R V$, and HaeIII) (relative frequencies are in parentheses).

\begin{tabular}{|c|c|c|c|c|c|c|}
\hline \multicolumn{2}{|c|}{ Composite haplotypes } & \multicolumn{5}{|c|}{ Geographic distribution of mtDNA composite haplotypes } \\
\hline & & Balashi & Chandpur & Cox's Bazar & Sundarbans & Kuakata \\
\hline I & AAAA & $3(0.167)$ & $4(0.222)$ & 0 & $1(0.056)$ & 0 \\
\hline II & AAAB & $1(0.055)$ & 0 & 0 & 0 & 0 \\
\hline III & ABAC & $1(0.055)$ & 0 & 0 & 0 & 0 \\
\hline IV & AAAC & $2(0.111)$ & 0 & 0 & 0 & 0 \\
\hline V & $\mathrm{ABCC}$ & $2(0.111)$ & 0 & 0 & 0 & 0 \\
\hline VI & $\mathrm{AABB}$ & $2(0.111)$ & $5(0.278)$ & $1(0.055)$ & $1(0.055)$ & $2(0.111)$ \\
\hline VII & $\mathrm{ABBB}$ & $1(0.055)$ & 0 & 0 & 0 & 0 \\
\hline VIII & AAAE & $1(0.055)$ & $1(0.055)$ & 0 & 0 & 0 \\
\hline IX & AACA & $1(0.055)$ & 0 & 0 & 0 & 0 \\
\hline $\mathrm{X}$ & AABB & $2(0.111)$ & 0 & 0 & 0 & 0 \\
\hline XI & AADA & $2(0.111)$ & $1(0.055)$ & $1(0.055)$ & $1(0.055)$ & $1(.055)$ \\
\hline XII & $\mathrm{ABAD}$ & 0 & $1(0.055)$ & 0 & 0 & 0 \\
\hline XIII & ACAA & 0 & $1(0.055)$ & 0 & 0 & 0 \\
\hline XIV & $\mathrm{AABC}$ & 0 & $2(0.111)$ & 0 & 0 & $2(0.111)$ \\
\hline $\mathrm{XV}$ & AADB & 0 & $1(0.055)$ & 0 & 0 & $1(0.055)$ \\
\hline XVI & $\mathrm{AABE}$ & 0 & $2(0.111)$ & 0 & $1(0.055)$ & 0 \\
\hline XVII & $\mathrm{AACB}$ & 0 & 0 & $3(0.167)$ & 0 & 0 \\
\hline XVIII & $\mathrm{AACF}$ & 0 & 0 & $2(0.111)$ & 0 & 0 \\
\hline XIX & $\mathrm{AACC}$ & 0 & 0 & $1(0.055)$ & 0 & 0 \\
\hline$X X$ & CBBA & 0 & 0 & $4(0.222)$ & 0 & $2(0.111)$ \\
\hline XXI & BADA & 0 & 0 & $1(0.055)$ & 0 & 0 \\
\hline XXII & $\mathrm{ABCD}$ & 0 & 0 & $1(0.055)$ & $1(0.055)$ & 0 \\
\hline XXIII & CACA & 0 & 0 & $1(0.055)$ & 0 & 0 \\
\hline XXIV & BACA & 0 & 0 & $1(0.055)$ & 0 & 0 \\
\hline XXV & AABG & 0 & 0 & $1(0.055)$ & 0 & 0 \\
\hline XXVI & AADC & 0 & 0 & $1(0.055)$ & 0 & 0 \\
\hline XXVII & BACB & 0 & 0 & 0 & $2(0.111)$ & 0 \\
\hline XXVIII & BADE & 0 & 0 & 0 & $3(0.167)$ & 0 \\
\hline XXIX & BABA & 0 & 0 & 0 & $2(0.111)$ & 0 \\
\hline XXX & BABB & 0 & 0 & 0 & $2(0.111)$ & $1(0.055$ \\
\hline XXXI & ABAE & 0 & 0 & 0 & $1(0.055)$ & $2(0.111)$ \\
\hline XXXII & AADG & 0 & 0 & 0 & $1(0.055)$ & $2(0.111)$ \\
\hline XXXIII & BAAE & 0 & 0 & 0 & $1(0.055)$ & $2(0.111)$ \\
\hline XXXIV & BADC & 0 & 0 & 0 & $1(0.055)$ & $2(0.111)$ \\
\hline XXXV & ABDB & 0 & 0 & 0 & 0 & $1(0.055)$ \\
\hline
\end{tabular}

Table 3 - Genetic variability within the five different populations of hilsa shad (T. ilisha).

\begin{tabular}{|c|c|c|c|c|c|}
\hline & \multicolumn{5}{|c|}{ Populations } \\
\hline & Balashi & Chandpur & Cox’s Bazar & Sundarbans & Kuakata \\
\hline Sample size & 18 & 18 & 18 & 18 & 18 \\
\hline N. of haplotypes & 11 & 9 & 12 & 13 & 11 \\
\hline N. of polymorphic sites & 20 & 20 & 23 & 24 & 19 \\
\hline Rate of haplotype & 0.611 & 0.500 & 0.667 & 0.722 & 0.611 \\
\hline Haplotype diversity & $0.948 \pm 0.05$ & $0.882 \pm 0.05$ & $0.967 \pm 0.03$ & $0.960 \pm 0.03$ & $0.954 \pm 0.02$ \\
\hline Expected heterozygosity (gene diversity) & $0.451 \pm 0.29$ & $0.363 \pm 0.26$ & $0.531 \pm 0.16$ & $0.569 \pm 0.24$ & $0.343 \pm 0.09$ \\
\hline Population specific $\mathrm{F}_{\mathrm{ST}}$ indices & 0.099 & 0.105 & 0.092 & 0.085 & 0.079 \\
\hline Tajima's D test & 0.751 & 0.150 & 1.280 & 0.082 & 0.565 \\
\hline Fu's Fs test & -1.057 & 0.178 & $-3-26$ & -1.899 & 2.814 \\
\hline
\end{tabular}


Table 4 - Estimates of pairwise $\mathrm{F}_{\mathrm{ST}}$ (Population differentiation) values (below diagonal) and genetic distance (above diagonal) among five T. ilisha populations in Bangladesh. The $\mathrm{F}_{\mathrm{ST}}$ values were calculated with 110 permutations.

\begin{tabular}{lllllc}
\hline & $\mathrm{Ba}$ & \multicolumn{1}{c}{$\mathrm{Ch}$} & \multicolumn{1}{c}{$\mathrm{CB}$} & $\mathrm{Su}$ & $\mathrm{Ku}$ \\
\hline $\mathrm{Ba}$ & 0.00000 & 0.00243 & 0.04816 & 0.07628 & 0.01959 \\
$\mathrm{Ch}$ & $0.00563 \mathrm{NS}$ & 0.00000 & 0.07252 & 0.07847 & 0.03334 \\
$\mathrm{CB}$ & $0.10497^{* * *}$ & $0.15380^{* * *}$ & 0.00000 & 0.05637 & 0.03402 \\
$\mathrm{Su}$ & $0.16109^{* * *}$ & $0.16531^{* * *}$ & $0.12173^{* * *}$ & 0.00000 & 0.00145 \\
$\mathrm{Ku}$ & $0.044120^{*}$ & $0.07391^{*}$ & $0.07536 \mathrm{NS}$ & $0.00334 \mathrm{NS}$ & 0.00000 \\
\hline
\end{tabular}

Note: Ba: Balashi, Ch: Chandpur, CB: Cox’s Bazar, Su: Sundarbans, Ku: Kuakata, NS: Not significant; *: p $<0.05 ; * * *: p<0.000$.

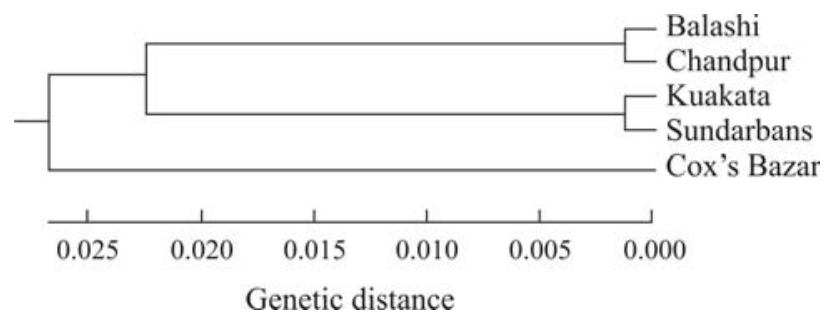

Figure 2 - UPGMA dendrogram summarising the genetic distance between pairs from the five different populations of T. ilisha.

Bangladesh. Geographic differentiation of the hilsa shad $T$. ilisha has also been reported previously. Brahmane et al. (2006) identified two groups of hilsa in India, one comprising the Ganges and Yamuna rivers and the other the Hooghly and Narmada rivers. Dahle et al. (1997) reported the existence of three stocks of hilsa shad in Bangladesh waters, namely the Chandpur (Meghna river), Barguna (Brackish water, near Kuakata)) and Cox's Bazar (salt water), when using RAPD markers. Our results suggest there are at least two, one marine, and the other riverineestuarine, or possibly three (riverine, estuarine and marine), stocks of hilsa in Bangladesh. The second possibility complies with the hypothesis of three groups of hilsa shad, anadromous, potamodromous and marine, as reported by Pillay and Rosa Jr (1963). Now, the question is whether the T. ilisha feeding in the Chandpur area migrate further upstream to spawn in the Padma and the Jamuna rivers or not. No significant difference in $\mathrm{F}_{\mathrm{ST}}$ value between the samples from Balashi (the Jamuna) and Chandpur (the Meghna) suggest a single panmictic riverine population of T. ilisha in Bangladesh. However, this conclusion may be contradicted through the presence of some private haplotypes in the Balashi and Chandpur populations. These results also run counter to those of Shifat et al. (2003), who reported that the two river populations of T. ilisha, the Meghna and the Padma were different stocks, though they observed certain alleles shared by some individuals of these two river samples. The presence of private haplotypes indicates the extent of mixing between populations. Due to their locations (Figure 1) and the mode of migration of the species, the possibility of mixing in the Chandpur (the mid Meghna river), Kuakata and Sundarbans populations is higher, re- flected by the lower number of private haplotypes in these populations. Higher numbers of private haplotypes have been obtained in the two most distant populations, Balashi and the Cox's Bazar (Table 2), which indicates that the low number of samples is not the main cause of the high number of private haplotypes in these populations. Therefore, we would like to opine that certain differences exist among the river populations, perhaps due to preferential movements of a fraction of the migratory groups, although the difference is not high enough to distinguish the populations as separate stocks (sub-populations).

We observed significant differentiation between the riverine and marine (Cox's Bazar) populations, but not between the marine and one of the estuarine. There is no evidence of spawning in the sea, but there is evidence of $T$. ilisha estuarine spawning in Bangladesh (BOBP, 1987). Thus, fishes from the Cox's Bazar region must migrate to any of the rivers or at least up to the estuaries. Our results suggest that fishes from the Cox's Bazar region may go up to the Kuakata region, but not to the Meghna and Jamuna rivers, as significant differentiations between the Cox's Bazar and the two river populations have been observed, but not between the Cox's Bazar and Kuakata (Table 4).

The five samples were grouped into two clusters on the basis of genetic distance among population-pairs. Nevertheless, the two clusters were finally divided into three groups corresponding to the three different environments, riverine, estuarine and marine (sea). The slight distance between the Balashi and Chandpur population indicates their belonging to the same stock. However, the sharing of two haplotypes by all the populations has led us to postulate the presence of a certain degree of gene flow among those studied.

Hilsa shad (T. ilisha) is the national fish of Bangladesh. The delicious taste and contribution of this fish has lead to its position as one of the most economically important fish in this country. Furthermore, hilsa fishery constitutes the largest single species fishery in the riverine, estuarine and marine ecosystems of the country. It is essential to recognize that geographically and genetically different populations as different stocks should be managed separately (Carvalho and Hauser, 1994). Our studies on mtDNA PCR-RFLP in T. ilisha indicate that population sub-division does indeed exist in this species. On the basis 
of the AMOVA, we can conclude that there are three stocks of hilsa with a substantial level of inter-population genetic divergence among river, estuarine and marine populations. The high level of haplotype variability found in only five populations underlines the usefulness of RFLPs of the D-loop region as molecular markers to investigate the geographic structure of T. ilisha. We analyzed only 18 individuals from each population, and the electrophoretic analysis of restriction fragments is also not so perfect as sequencing the PCR product. Therefore, to reach a more definite conclusion, larger samples from throughout the distribution range of the species in the country should be analyzed by sequencing the mtDNA D-loop region and/or with faster evolving molecular markers, such as micro-satellite loci.

\section{Acknowledgments}

The research was carried out under a Special Allocation for Science and Information \& Communication Technology project (2005-2006) of the Ministry of Science and Information \& Communication Technology, Government of the People's Republic of Bangladesh.

\section{References}

Avise JC, Bowen BW and Lamb T (1989) DNA fingerprints from hypervariable mitochondrial genotypes. Mol Biol Evol 6:258-269.

Avise JC (2004) Molecular Markers, Natural History and Evolution. 2nd edition. Chapman and Hall, London, $511 \mathrm{pp.}$

BOBP (1987) Hilsa investigation in Bangladesh. Bay of Bengal Programme (BOBP). UNDP, Colombo, 113 pp.

Brahmane MP, Das MK, Sinha MR, Sugunan VV, Mukherjee A, Singh SN, Prakash S, Maurye P and Hajra A (2006) Use of RAPD fingerprinting for delineating populations of hilsa shad Tenualosa ilisha (Hamilton, 1822). Genet Mol Res 5:643-652.

Carvalho GR and Hauser L (1994) Molecular genetics and the stock concept in fisheries. Rev Fish Biol Fish 4:326-350.

Dahle G, Rahman M and Erikson AG (1997) RAPD fingerprinting used for discriminating among three populations of Hilsa shad (Tenualosa ilisha). Fish Res 32:263-269.

DoF (2006) Fishery Statistical Year Book of Bangladesh 20052006. 23rd edition. Department of Fisheries, Government of the People's Republic of Bangladesh, $87 \mathrm{pp}$.

Excoffier L, Smouse PE and Quattro JM (1992) Analysis of molecular variance inferred from metric distances among DNA haplotypes: Application to human mitochondrial DNA restriction data. Genetics 131:479-491.

Excoffier L, Laval G and Schneider S (2005) ARLEQUIN v. 3.0: An integrated software package for population genetics data analysis. Evol Bioinform Online 1:47-50.

Fu YX (1997) Statistical tests of neutrality of mutations against population growth, hitchhiking and background selection. Genetics 147:915-925.

Graves JE and McDowell JR (1994) Genetic analysis of striped marlin (Tetrapturus audax) population structure in the Pacific Ocean. Can J Fish Aquat Sci 51:1762-1768.
Islam MS and Alam MS (2004) Randomly amplified polymorphic DNA analysis of four different populations of the Indian major carp Labeo rohita (Hamilton). J Appl Ichthyol 20:407412.

Martin AP, Humphreys R and Palumbi SR (1992) Population genetic structure of the armorhead, Pseudopentaceros wheeler, in the North Pacific Ocean: Application of the polymerase chain reaction to fisheries problems. Can J Fish Aquat Sci 49:2386-2391.

Milton DA and Chenery SR (2001) Can otolith chemistry detect the population structure of the shad hilsa Tenualosa ilisha? Comparison with the results of genetic and morphological studies. Mar Ecol Prog Ser 222:239-251.

Nurul Amin SM, Rahman MA, Haldar GC, Mazid MA, Milton DA and Blabber SJM (2004) Stock assessment and management of Tenulosa ilisha in Bangladesh. Asian Fish Sci 17:50-59.

Nash JHE (1991) DNAfrag, v. 3.03. Institute for Biological Sciences, Ottawa.

Nei M (1987) Molecular Evolutionary Genetics. University Press, New York, pp 176-207.

Pillay SR and Rosa Jr H (1963) Synopsis of biological data on hilsa, Hilsa ilisha (Hamilton 1882). FAO Fish Biol Synops n. 25, Rome, 63 pp.

Rahman M and Naevdal G (2000) Population genetic studies of hilsa shad, Tenualosa ilisha (Hamilton), in Bangladesh waters: Evidence for the existence of separate gene pools. Fish Manag Ecol 7:401-411.

Raja BTA (1985) A review of the biology and fisheries of Hilsa ilisha in the upper Bay of Bengal. Food and Agriculture Organization of the United Nations, Rome, $70 \mathrm{pp}$.

Reynolds J, Weir BS and Cockerham CC (1983) Estimation for the co-ancestry coefficient: Basis for a short term genetic distance. Genetics 105:767-779.

Salini JP, Miltona DA, Rahman MJ and Hussain MG (2004) Allozyme and morphological variation throughout the geographic range of the tropical shad, hilsa Tenualosa ilisha. Fish Res 66:53-69.

Santos MCF, Ruffino ML and Farias JP (2007) High levels of genetic variability and panmixia of the tambaqui Colossoma macropomum (Cuvier, 1816) in the main channel of the Amazon River. J Fish Biol 71(Suppl.):33-44.

Shifat R, Begum A and Khan H (2003) Use of RAPD fingerprinting for discriminating two populations of Hilsa shad (Tenualosa ilisha Ham.) from inland rivers of Bangladesh. J Biochem Mol Biol 36:462-467.

Tabata K and Mizuta A (1997) RFLP analysis of the mtDNA D-loop region in red seabream Pagrus major populations from locations of western Japan. Fish Sci 63:211-217.

Tajima F (1989) Statistical method for testing the neutral mutation hypothesis by DNA polymorphism. Genetics 123:585-595.

Tamura K, Dudley J, Nei M and Kumar S (2007) MEGA4: Molecular Evolutionary Genetics Analysis (MEGA) software v. 4.0. Mol Biol Evol 24:1596-1599.

Weir BS and Cockerham CC (1984) Estimating F-statistics for the analysis of population structure. Evolution 38:1358-1370.

Associate Editor: Fábio de Melo Sene

License information: This is an open-access article distributed under the terms of the Creative Commons Attribution License, which permits unrestricted use, distribution, and reproduction in any medium, provided the original work is properly cited. 